\title{
IMPACT OF TH17/TREGFOXP3 CELLS RATIO ON RHEUMATOID ARTHRITIS PATIENTS RECEIVING ANTI TNF- THERAPY-.
}

\author{
Enas Riyadh Mohsen and NaAel H. Ali \\ College of Medicine, University of Basrah-Iraq
}

(Received: September 25, 2021; Accepted for Publication: October 24, 2021)

\begin{abstract}
In order to determine the correlation between disease activity of RA with the Th17/TregFoxp3 cells ratio in patients undertherapy with Anti-TNF-alpha which is the aim of present study, Ninety-seven patients with RA and healthy control groups were included in this case control study, eighty-four patients divided into four groups; 25 patients receiving only MTX; 18 patients receiving monotherapy (anti- TNF); 26 patients receiving combined therapy (MTX + anti-TNF); 15 patients with RA not receiving any drug (positive control). Other thirteen healthy people considered as negative control were enrolled in this study. Patients with RA were attending Basrah General Hospital, Rheumatology Unite, Biological Therapy Center for receiving anti-TNF therapy. Flowcytometry was used for measuring TregFoxp3 and Th17 markers and DAS-28 score was used for measuring RA disease activity. Anti TNF inhibitors (Infliximab and Etanercept) were measured as well. Other inflammatory and hematological parameters were also measured (ESR, total WBC, Lymphocytes, monocytes and neutrophil counts). Resulted, DAS-28 as disease activity score was significantly correlated with Th17/ TregFoxp3 ratio and with the TH17 cells count. Statistically, Th17/ TregFoxp3 ration was not correlated with BMI, morning stiffness, and duration of the disease. In a Conclusion, Th17/Treg Foxp3 ratio correlated significantly with DAS-28 as RA disease activity. The lower Tregs Foxp3 frequency, the higher the DAS score reflecting higher disease activity. In combined therapy group, disease activity was found lower than other patient groups indicating for the effect of this combination between MTX and anti-TNF. Herein, we demonstrated that the main advantage of this combined therapy in RA patients was the reversion of Th17 cell expansion.
\end{abstract}

KEY WORDS: Anti-TNF; immunotherapy; Infliximab; Etanercept; Rheumatoid Arthritis; Th17/Treg Foxp3 ratio.

\section{INTRODUCTION}

$\mathbf{R}$ heumatoid arthritis (RA) a multifactorial origin autoimmune disease, associated with chronic inflammation and articular destruction in the joints. The pathogenesis determined by induction and progression of abnormal regulatory $\mathrm{T}$ cell (Treg) response with a shift towards a Th17 cell response (Ohkura, Kitagawa and Sakaguchi, 2013). The Treg $\left(\mathrm{CD} 4^{+} \mathrm{CD} 25^{+}\right)$cells play a role in maintain homeostasis by mediate immune tolerance and suppress autoreactive lymphocytes. This homeostasis has been found to be altered in active RA (Flores-Borja et al., 2008; Chen et al., 2011). Th17 cells another player in the pathogenesis of RA, they secret certain proinflammatory cytokines, like Interleukin-17A (IL-17A) (Lee, 2018). Both IL-17A and Tumor Necrosis Factor- $\alpha$ (TNF- $\alpha$ ) act to induce chemokine and cytokine production from synovial fibroblasts, resulting in destruction of cartilage (Aravena et al., 2011). So, anti-TNF- $\alpha$ therapy has been found to improve the ability of Tregs in regulation and decreases Th17 cell populations (Ohkura, Kitagawa and Sakaguchi, 2013). This immunomodulatory therapy has faced a number of challenges. A proportion of patients (30-40\%) fail to respond to anti-TNF therapy, that make them to have adverse effects and loss of response as their disease progressively worsens (Lina et al., 2011; S. et al., 2012; Thomas et al., 2015). The explanation papers for this irresponsiveness were scarce. Recently, neutralizing Anti-Drug Antibodies (ADA) interferes with the ability of TNF inhibitors (TNFi) to block TNF- $\alpha$ (Atiqi et al., 2020). These blockers directed against idiotopes inside or outside the TNF-binding fragments of the anti-TNF- $\alpha$ (Bendtzen, 2015). Others resulted that, alteration in the Th17/Treg ratio in combination with an imbalance in the Th1/Th2 
ratio are responsible for RA diseases activity and progression of RA (Chen et al., 2012). Immunomodulatory drugs like Adalimumab and Etanercept have no effect on change in number or phenotype of peripheral blood Tregs in RA patients even in conjunction with methotrexate (MTX) (Blache et al., 2011).

Forkhead box protein 3(FoxP3), a transcription factor responsible for the development of Tregs in the thymus, and it needed to maintain the suppressive ability of Tregs in the human peripheral blood. Decreased of FoxP3 expression might lead to conversion of Tregs from regulatory into effector cells (Th17) (Williams and Rudensky, 2007; Hori, Nomura and Sakaguchi, 2017). That might lead toTh17/Treg cells imbalance. Pro- or antiinflammatory cytokines production is connected with this imbalance and is relevant for the development and/or progression of the disease(Aravena et al., 2011). Both rely on (Transforming Growth Factor- $\beta$ ) TGF- $\beta$ for their induction. But, when the level of Interleukin-6 (IL-6) is increased, Th17 response is favored (Zheng, Wang and Horwitz, 2008). Thus, FoxP3 expression is critical for the identification of Tregs that carry suppressive activity. A matter which neglected by other similar study (Taha et al., 2019) . Th17/Treg ratio used as biomarker, predictive marker, and progression marker for many autoimmune diseases(Lee, 2018). Herein this study we hypothesized, this ratio correlated with the activity of RA disease especially among those receive anti-TNF therapy. The aim of the present study is to investigate the correlation between Th17/Treg FoxP3 cells with the RA disease activity in patients undertherapy with Anti-TNF$\alpha$.

\section{Patients and Methods}

\section{A. Study population}

A total of ninety-seven participants were included in this case control study, conducting from August/2019 to February/2020. Eighty-four of them were patients with RA attending Basrah General Hospital, Rheumatology Unite, Biological Therapy Center for receiving antiTNF therapy. Negative control group includes thirteen healthy individuals. The number, age, and gender of participants according to group are shown in below Table-A.

Table (A): Characteristic feature of patients and control groups

\begin{tabular}{|c|c|c|c|c|}
\hline Group No. & Character & $\mathbf{N}$ & $\begin{array}{l}\text { Age range (years) } \\
\text { (median) }\end{array}$ & $\begin{array}{l}\text { Females } \\
\text { No. (\%) }\end{array}$ \\
\hline G1 & Methotrexate (MXT) only & 25 & $\begin{array}{c}(20-79) \\
(52) \\
\end{array}$ & $18(72.0)$ \\
\hline G2 & Monotherapy (anti-TNF) & 18 & $\begin{array}{c}(33-69) \\
(53)\end{array}$ & $11(61.1)$ \\
\hline G3 & $\begin{array}{l}\text { Combined therapy (antiTNF } \\
+\mathrm{MXT})\end{array}$ & 26 & $\begin{array}{c}(25-71) \\
(50) \\
\end{array}$ & $24(92.3)$ \\
\hline G4 & $\begin{array}{l}\text { Positive control } \\
\text { (Naïve patients) }\end{array}$ & 15 & $\begin{array}{l}(20-65) \\
(48)\end{array}$ & $10(66.7)$ \\
\hline Total & & 84 & $\begin{array}{l}(20-79) \\
(50)\end{array}$ & 71 (73.2) \\
\hline G5 & $\begin{array}{l}\text { Negative control } \\
\text { (Healthy) }\end{array}$ & 13 & $\begin{array}{l}(25-67) \\
(43)\end{array}$ & $8(61.5)$ \\
\hline
\end{tabular}

Information about socio-demographic and clinical features were obtained prior to collect the blood sample from all participants. Information include: body weight, treatment information, clinical presentation and disease activity. The Clinical parameters was obtained according to 2010 EULAR/ ACR criteria (DAS 28). Patients receiving anti-TNF from at least six doses and their age more than 18 years were included in the study. Patients with other autoimmune or chronic diseases, switch to other drugs, irregular therapy, overlap diseases, receiving corticosteroid drugs, or pregnant women were excluded.

\section{B. Sampling and processing}

Five $\mathrm{ml}$ of blood sample were collected from all participants for flowcytometry and other laboratory investigations. 
Flow Cytometry work

BriCyteE6 (Mindray, China) flowcytometry was used for $\mathrm{T}$ cells phenotyping which equipped with dual-laser based optics. A red diode laser and a blue diode laser is used for exciting 4 to 6 colors of fluorescence lights. For Treg (CD4+CD25+Foxp3+) cells enumeration flowcytometry: After RBC lysis, ten ul of Mouse anti-human CD4 fluorescein conjugated FITC (Becton Dickinson, San Jose, CA, USA, BD) monoclonal antibodies $(\mathrm{mAb})$ and Mouse antihuman CD25 (IL-2R $\alpha$ ) phycoerythrin PE labelled (BD) mAbs were incubated for $45 \mathrm{~min}$. Following surface staining, cells were fixed and permeabilized using BD Fixation-permebiliztion Kit. The cells then were re-suspended in $250 \mathrm{ul}$ by cytofix and incubated for 20 minutes at $4^{\circ} \mathrm{C}$ then washed. Ten ul of polyclonal antihuman/mouse/rat Foxp3-Allophycocyanin, APC conjugated (e Bioscience, USA), were incubated with the cells overnight in the dark. Unstained cells, as isotypic control, were used to exclude autofluoresence.

Th17 cells were quantified by recombinant human IgG1 to CD196 (CCR6) and CD194 (CCR4) ((Bio-Connect Diagnostics B.V. The Netherlands). According to product instructions, the recommended antibody dilution for labeling of cells and subsequent analysis by flow cytometry was $1: 50$ for up to 106 cells $/ 100 \mu \mathrm{L}$. Up to 106 was re-suspended nucleated cells per $98 \mu \mathrm{L}$ of buffer. Then $2 \mu \mathrm{L}$ was added of the antibody. Mixture was mixed well and incubated for 10 minutes in the dark in the refrigerator $\left(2-8^{\circ} \mathrm{C}\right)$. Attention made for avoiding the higher temperatures and/or longer incubation times to avoid non-specific cell labeling. cells were washed by adding 1-2 $\mathrm{mL}$ of buffer and centrifuged at $300 \times \mathrm{g}$ for 10 minutes. Then the supernatant was aspirated completely. Resuspended cell pellet in a suitable amount of buffer and analyzed by flowcytometry. Treg FoxP3/Th17 ratio was calculated according to the output resulted from flowcytometry.

Enzyme immunoassay for the qualitative determination of antibodies in serum to Etanercept $\left(\right.$ Enbrel $\left.^{\circledR}\right)$ and Infliximab $\left(\right.$ Remicade $\left.^{\circledR}\right)$ :

Anti TNF- $\alpha$ inhibitors antibodies (ADA) (Infliximab and Etanercept) were measured as well for each participants by using ELISA method by using Matriks Biotek ${ }^{\circledR}$ kits. According to manufactures instructions, the ADA were measured for only three groups of the study (monotherapy, combined therapy and control positive groups).

Other blood parameters: total white blood cells; Total lymphocytes; neutrophil; monocytes $\left(10^{9}\right.$ cell/L); and ESR were done for each participants.

\section{Statistical analysis}

Data was entered and analyzed by using the statistical package for social sciences (SPSS) software for windows, version 26. The data in the present study was nonparametric. Therefore, the statistical methods used in accordance with this type of data. Descriptive statistics were presented as median for quantitative data, frequencies and percentages (\%) according to the types of the variables. Chi-square and Fishers Exact Test were used to compare the proportion and frequencies, Kruskal Wallis Test used to compare the median of different study groups, Level of significance (P value) of $\leq 0.05$ considered significant. Spearman Test was used for correlation between variables in the study.

\section{Results}

Table-1 shows sociodemographic features (Age, Sex, residency, and smoking tobacco) with no significant differences between patients and control groups.

The clinical features including BMI, age onset of the diseases, duration of the disease, morning stiffness (minutes), family history, history of primary and secondary failure, and DAS-28 among patients and controls groups. Resulted that only DAS-28 and family history were significantly difference between groups with prominence to patients receiving only MTX. Table-3 shows the flowcytometry outcome for all five groups. The markers Th17, Treg, Treg Foxp3, and Th17/Treg Foxp3 ratio were significantly difference $(\mathrm{P}<0.01)$, while CD4 marker was insignificant between five groups. Laboratory investigations including WBC count, ESR, total lymphocyte count were significant difference between all five groups. Other investigation neutrophil and monocytes were insignificant difference (Table-3).

Correlations results between Th17/TregFoxP3 ratio with some clinical features were insignificant in patient's groups (Table-4). Table-5 shows the correlations between disease activity and flowcytometry outcomes including Th17/TregFoxP3 ratio. Significantly (at the level of 0.05 ) positive correlation betweenTh17 /Treg Foxp3+ T cells ratio and disease activity score in patient's groups by Spearmann's correlation test $(\mathrm{r}=$ 
0.231, $\mathrm{P}=0.034$ ) (Fig-1), also with Th17 ( $\mathrm{r}=$ $0.226, \quad \mathrm{P}=0.039$ ) (Fig-2). TregFoxP3 was insignificantly correlated with disease activity in patient's groups.

Anti-TNFi (ADA) were found among those who received Infliximab more than Etanercept (table-6) with significant difference $(\mathrm{P}<0.05)$ between monotherapy, combined therapy and positive control groups.

\section{Discussion}

The ratio or balance between Th17 and Treg is critically important for pathogenesis, prognosis, and therapy of many autoimmune diseases including RA (Taha et al., 2019). In animal models, re-establishing the $\mathrm{T}$ effector/ Treg ratio can control the autoimmune responses. The published information about the correlation of this ratio as marker for immunotherapy and its correlation with disease activity were sparse. It is unclear whether the ratio of Th17/Treg in the peripheral blood of RA patients receiving anti-TNF is altered. In present study two CD markers (CD 194 and CD 196) were used for identification of Th17 by flowcytometry, revealed increased of Th17 significantly in RA patients with only methotrexate treatment than the other groups, while, Tregs $\left(\mathrm{CD}^{+} \mathrm{25}^{+}\right.$Foxp3) were significantly increased in healthy group. In humans, Tregs constitute about $5-10 \%$ of the $\mathrm{CD} 4+\mathrm{T}$ cell population in the peripheral blood of healthy individuals. These cells express high levels of CD25 (IL2Ra). They are also characterized by expression of the lineagespecific transcription factor -Foxp3, which is pivotal for Treg function and homeostasis (Hori, Nomura and Sakaguchi, 2017; Romano et al., 2019). Foxp3 was neglected by other researchers (Blache et al., 2011), so that might lead to controversy results in Treg function. In the present study, the TregFoxp3 counts approximately $50 \%$ of the total count of Treg in all patients and control groups. Therefore, we recommend to investigate Treg Foxp3 for more precision in describing their homeostasis and regulatory activity. That is come in agreement with Komatsu N, et al, 2014 (Komatsu et al., 2014), resulted that exTreg cells were a subset of Treg which converted to Th17 in inflammatory environment in autoimmune arthritis. Therefore, the strengthen on future resolution and therapy of autoimmune diseases depending on stabilization of Treg Foxp3 function at same time dampen proinflammatory cytokines like IL-
17. So, it reasonable, in the present study, Th17/Treg Foxp3 ratio used as biomarker.

Important result in present study was Th17/Treg Foxp3 ratio correlated significantly with DAS-28 a matter which represent the lower Tregs Foxp3 frequency, the higher the DAS score, reflecting higher disease activity and vice versa. In combined therapy group, disease activity was found lower than other patient groups indicating for the effect of this combination between MTX and anti-TNF. Herein, we demonstrated that the main advantage of this combined therapy in RA patients was the reversion of Th17 cell expansion. Many authors resulted unchanged outcome (Shen et al., 2010; Lina et al., 2011) or a decreased Th17 frequency following treatment with MTX and/or TNFi (Chen et al., 2012), and the latter findings are in accordance with the current study. Anti-TNF therapy with MTX was able to effectively limit the Th17 population only in the patients with early disease (S. et al., 2012). However, many papers strengthen that the effectiveness of anti-TNF therapy concerning Th17 expansion should be evaluated not earlier than 12 weeks after biologics usage irrespective of the MTX administration (Chen et al., 2011; Daekh, Mohammed and Ali, 2020).

Molecularly, the imbalance between Th17 and Treg cells is supported (Zhou et al., 2008), resulted both Th17 and Treg cells require the same cytokine Transforming Growth Factor- $\beta 1$ (TGF-beta1) during the early stage of differentiation. Foxp3 downregulated when other transcription factor, essential for Th17 development, like ROR $\gamma \mathrm{t}$ overexpressed especially in the presence of IL-1b and IL-6. This last research might strengthen our results. In the other side, IL-2, which is required for the expansion and maintenance of FoxP3 expressing Treg cells, has been found to inhibit the development of Th17 cells (Zheng, Wang and Horwitz, 2008). Therefore, IL-2 and IL-6 have counteractive effects of on the development and differentiation of Th17 and Treg in the periphery which may hamper immunoregulatory responses and facilitate the persistence of autoimmune inflammation.

Concerning immunogenicity to TNF antagonists, in present study Etanercept has lower immunogenicity than Infliximab. That result may be due to the well-known infliximab is a purified, recombinant DNA-derived chimeric human-mouse IgG monoclonal antibody and contains murine heavy $(\mathrm{H})$ and 
light (L) chain variable regions, ligated to genomic human heavy and light chain constant regions, while Etanercept is a fusion-protein between a human IgG1 Fc-tail and the TNFreceptor type 2(Levin, Wildenberg and van den Brink, 2016; Atiqi et al., 2020; Bodio et al., 2020). A fact which make infliximab more immunogenicity than Etanercept. Studies on rheumatology patients identified different genetic factors associated with reduced response to infliximab(Talotta et al., 2015). However, patient-specific predictors of infliximab immunogenicity have not been identified so far. That gap has precluded a rational tailoring of individualized therapy, namely, prescribing combination MTX-infliximab therapy (combined therapy group) to those patients with high risk of infliximab immunogenicity.

In a conclusion, Th17/Treg Foxp3 ratio correlated significantly with DAS-28 as RA disease activity. The lower Tregs Foxp3 frequency, the higher the DAS score reflecting higher disease activity. In combined therapy group, disease activity was found lower than other patient groups indicating for the effect of this combination between MTX and anti-TNF. Herein, we demonstrated that the main advantage of this combined therapy in RA patients was the reversion of Th17 cell expansion.

prescribing combination MTX-infliximab therapy to those patients with high risk of infliximab immunogenicity, sparing them from developing antibodies to infliximab and its risks and side effects.

\section{Acknowledgements}

The authors would like to thank $\mathrm{Dr}$ Muhammad AlMussawi for his keen assistant in flowcytometry work, without which, this study would not have been possible.

\section{Disclosure}

The authors declared no conflicts of interest. No funding was received for this study.

\section{REFERENCES}

Aravena, O. et al. (2011) 'Anti-TNF therapy in patients with rheumatoid arthritis decreases Th1 and Th17 cell populations and expands IFN- $\gamma$-producing NK cell and regulatory $\mathrm{T}$ cell subsets', Immunobiology, 216(12), pp. 1256-1263. doi: 10.1016/j.imbio.2011.07.006.

Atiqi, S. et al. (2020) 'Immunogenicity of TNFInhibitors', Frontiers in Immunology, 11(February), pp. 1-13. doi: 10.3389/fimmu.2020.00312.

Bendtzen, K. (2015) 'Immunogenicity of antiTNF- $\alpha$ biotherapies: II. Clinical relevance of methods used for anti-drug antibody detection', Frontiers in Immunology, 6(APR), pp. 1-5. doi: 10.3389/fimmu.2015.00109.

Blache, C. et al. (2011) 'Number and phenotype of rheumatoid arthritis patients' CD4+CD25hi regulatory $\mathrm{T}$ cells are not affected by adalimumab or etanercept', Rheumatology, 50(10), pp. 1814-1822. doi: 10.1093/rheumatology/ker183.

Bodio, C. et al. (2020) 'Personalized medicine in rheumatoid arthritis: How immunogenicity impacts use of TNF inhibitors', Autoimmunity Reviews, 19(5), p. $102509 . \quad$ doi: 10.1016/j.autrev.2020.102509.

Chen, D. Y. et al. (2011) 'Increasing levels of circulating Th17 cells and interleukin-17 in rheumatoid arthritis patients with an inadequate response to anti-TNF- $\alpha$ therapy', Arthritis Research and Therapy, 13(4), p. R126. doi: 10.1186/ar3431.

Chen, J. et al. (2012) 'Comprehensive evaluation of different t-helper cell subsets differentiation and function in rheumatoid arthritis', Journal of Biomedicine and Biotechnology, 2012. doi: 10.1155/2012/535361.

Daekh, N. A. K., Mohammed, K. A. and Ali, N. H. (2020) 'Polymorphism of HLA-B27 among Ankylosing Spondylitis Patients in Basrah, Iraq', Scientific Journal of Medical Research, 04(13), pp. 12-16. doi: 10.37623/sjmr.2020.41303.

Flores-Borja, F. et al. (2008) 'Defects in CTLA4 are associated with abnormal regulatory T cell function in rheumatoid arthritis', Proceedings of the National Academy of Sciences of the United States of America, 105(49), pp. 19396-19401. doi: 10.1073/pnas.0806855105.

Hori, S., Nomura, T. and Sakaguchi, S. (2017) 'Control of regulatory T cell development by the transcription factor Foxp3', Journal of Immunology, 198(3), pp. 981-985. doi: $10.1126 /$ science. 1079490 .

Komatsu, N. et al. (2014) 'Pathogenic conversion of Foxp3 + T cells into TH17 cells in autoimmune arthritis', Nature Medicine, 20(1), pp. 62-68. doi: $10.1038 / \mathrm{nm} .3432$.

Lee, G. R. (2018) 'The balance of th17 versus 
treg cells in autoimmunity', International Journal of Molecular Sciences, 19(3), pp. 1-14. doi: 10.3390/ijms 19030730.

Levin, A. D., Wildenberg, M. E. and van den Brink, G. R. (2016) 'Mechanism of action of anti-TNF therapy in inflammatory bowel disease', Journal of Crohn's and Colitis, 10(8), pp. 989-997. doi: 10.1093/ecco-jcc/jjw053.

Lina, C. et al. (2011) 'Combined treatment of etanercept and MTX reverses Th1/Th2, Th17/Treg imbalance in patients with rheumatoid arthritis', Journal of Clinical Immunology, 31(4), pp. 596-605. doi: 10.1007/s10875-011-9542-6.

Ohkura, N., Kitagawa, Y. and Sakaguchi, S. (2013) 'Development and Maintenance of Regulatory T cells', Immunity, 38(3), pp. 414-423. doi: 10.1016/j.immuni.2013.03.002.

Romano, M. et al. (2019) 'Past, present, and future of regulatory $\mathrm{T}$ cell therapy in transplantation and autoimmunity', Frontiers in Immunology, 10(JAN). doi: 10.3389/fimmu.2019.00043.

S., A. et al. (2012) 'Incomplete response of inflammatory arthritis to TNF $\alpha$ blockade is associated with the Th17 pathway.', Annals of the rheumatic diseases, 71(10), pp. 1741-1748. Available at: http://www.embase.com/search/results?su baction $=$ viewrecord $\&$ from $=$ export $\&$ id $=$ L3 66349584\%0Ahttp://sfx.library.uu.nl/utre cht?sid=EMBASE $\&$ issn $=14682060 \& i d=d$ oi:\&atitle=Incomplete+response+of+infla mmatory+arthritis + to $+\mathrm{TNF} \alpha+$ blockade + is +associated+with+the+Th17+pa.

Shen, H. et al. (2010) 'Infliximab educes the Frequency of Interleukin 17-Producing Cells and the Amounts of Interleukin 17 in Patients with heumatoid Arthritis', Journal of Investigative Medicine, 58(7), pp. 905-908. doi: 10.2310/JIM.0b013e3181eb9895.

Taha, H. A. et al. (2019) 'Investigating the Balance between Th17/Treg Cells in Rheumatoid Arthritis and its Association with Disease Activity', Journal of Child Science, 9(1), pp. E75-E83. doi: $10.1055 / \mathrm{s}-0039-1693158$.

Talotta, R. et al. (2015) 'Paradoxical Expansion of Th1 and Th17 Lymphocytes in Rheumatoid Arthritis Following Infliximab Treatment: a Possible Explanation for a Lack of Clinical Response', Journal of Clinical Immunology, 35(6), pp. 550-557. doi: 10.1007/s10875-015-0182-0.

Thomas, S. S. et al. (2015) 'Comparative Immunogenicity of TNF Inhibitors: Impact on Clinical Efficacy and Tolerability in the Management of Autoimmune Diseases. A Systematic Review and Meta-Analysis', BioDrugs, 29(4), pp. 241-258. doi: 10.1007/s40259015-0134-5.

Williams, L. M. and Rudensky, A. Y. (2007) 'Maintenance of the Foxp3-dependent developmental program in mature regulatory $\mathrm{T}$ cells requires continued expression of Foxp3', Nature Immunology, 8(3), pp. 277-284. doi: 10.1038/ni1437.

Zheng, S. G., Wang, J. and Horwitz, D. A. (2008) ' Cutting Edge: Foxp3 + CD4 + CD25 + Regulatory $\mathrm{T}$ Cells Induced by IL-2 and TGF- $\beta$ Are Resistant to Th17 Conversion by IL-6 ', The Journal of Immunology, 180(11), pp. 7112-7116. doi: 10.4049/jimmunol.180.11.7112.

Zhou, L. et al. (2008) 'Provided Mice for FateMapping Experiments', 453(7192), pp. 236-240. 
Table (1): Sociodemographic features of Patients and controls.

\begin{tabular}{|c|c|c|c|c|c|c|c|}
\hline \multicolumn{2}{|l|}{$\begin{array}{l}\text { Sociodemographic } \\
\text { features }\end{array}$} & $\begin{array}{l}\text { MTX } \\
\text { n (25) }\end{array}$ & $\begin{array}{l}\text { Monotherapy } \\
\text { n (18) }\end{array}$ & $\begin{array}{l}\text { Combined therapy } \\
\mathrm{n}(26)\end{array}$ & $\begin{array}{l}\text { Positive } \\
\text { control } \\
\mathrm{n}(15)\end{array}$ & $\begin{array}{l}\text { Negative control } \\
\mathrm{n}(13)\end{array}$ & $\begin{array}{l}P . \\
\text { value }\end{array}$ \\
\hline \multirow{2}{*}{$\begin{array}{l}\text { Age } \\
\text { (years) }\end{array}$} & Median & 52.00 & 53.50 & 50.00 & 48.00 & 53.00 & 0.360 \\
\hline & $(\min -\max )$ & $(20-79)$ & $(33-69)$ & $(25-71)$ & $(20-65)$ & $(25-67)$ & \\
\hline \multirow[t]{2}{*}{ Sex } & $\begin{array}{l}\text { Male } \\
\mathrm{n}(\%)\end{array}$ & $\begin{array}{l}7 \\
(28 \%)\end{array}$ & $\begin{array}{l}7 \\
(38.9 \%)\end{array}$ & $\begin{array}{l}2 \\
(7.3 \%)\end{array}$ & $\begin{array}{l}5 \\
(26.8 \%)\end{array}$ & $\begin{array}{l}5 \\
(38.5 \%)\end{array}$ & 0.073 \\
\hline & $\begin{array}{l}\text { Female } \\
\mathrm{n}(\%)\end{array}$ & $\begin{array}{l}18 \\
(72 \%)\end{array}$ & $\begin{array}{l}11 \\
(61.1 \%)\end{array}$ & $\begin{array}{l}24 \\
(92.7 \%)\end{array}$ & $\begin{array}{l}10 \\
(73.2 \%)\end{array}$ & $\begin{array}{l}8 \\
61.5 \%)\end{array}$ & \\
\hline \multirow[t]{2}{*}{ Residency } & $\begin{array}{l}\text { Urban } \\
\mathrm{n}(\%)\end{array}$ & $\begin{array}{l}4 \\
(16 \%)\end{array}$ & $\begin{array}{l}5 \\
(27.8 \%)\end{array}$ & $\begin{array}{l}8 \\
(30.8 \%)\end{array}$ & $\begin{array}{l}3 \\
(20 \%)\end{array}$ & $\begin{array}{l}4 \\
(30.8 \%)\end{array}$ & 0.724 \\
\hline & $\begin{array}{l}\text { Rural } \\
\mathrm{n}(\%)\end{array}$ & $\begin{array}{l}21 \\
(84 \%)\end{array}$ & $\begin{array}{l}13 \\
(66.7 \%)\end{array}$ & $\begin{array}{l}18 \\
(69.2 \%)\end{array}$ & $\begin{array}{l}12 \\
(80 \%)\end{array}$ & $\begin{array}{l}9 \\
(96.2 \%)\end{array}$ & \\
\hline \multirow[t]{2}{*}{ Smoking } & $\begin{array}{l}\text { smoking } \\
\mathrm{n}(\%)\end{array}$ & $3(12.0 \%)$ & $\begin{array}{l}3 \\
(16.7 \%)\end{array}$ & $\begin{array}{l}5 \\
(19.2 \%)\end{array}$ & $\begin{array}{l}3 \\
(20.0 \%)\end{array}$ & $\begin{array}{l}0 \\
(0.0 \%)\end{array}$ & 0.502 \\
\hline & $\begin{array}{l}\text { Nonsmoking } \\
\mathrm{n}(\%)\end{array}$ & $\begin{array}{l}22 \\
(88.0 \%)\end{array}$ & $\begin{array}{l}15 \\
(83.3 \%)\end{array}$ & $\begin{array}{l}21 \\
(80.8 \%)\end{array}$ & $\begin{array}{l}12 \\
(80.0 \%)\end{array}$ & $\begin{array}{l}13 \\
(100 \%)\end{array}$ & \\
\hline
\end{tabular}


Table (2): clinical features of patients and controls groups

\begin{tabular}{|c|c|c|c|c|c|c|}
\hline Features & & MTX & Monotherapy & Combined therapy & Positive control & P. value \\
\hline \multirow[t]{2}{*}{ BMI } & $\mathrm{n}$ & 25 & 18 & 26 & 15 & 0.228 \\
\hline & $\begin{array}{l}\text { Median } \\
(\text { min-max })\end{array}$ & $\begin{array}{l}25.7100 \\
(16.30-40.00)\end{array}$ & $\begin{array}{l}30.4800 \\
(24.34-34.67)\end{array}$ & $\begin{array}{l}27.6250 \\
(2.50-44.92)\end{array}$ & $\begin{array}{l}27.4100 \\
(3.00-37.57)\end{array}$ & \\
\hline \multirow{2}{*}{$\begin{array}{l}\text { Age onset of the } \\
\text { disease } \\
\text { (years) }\end{array}$} & $\mathrm{n}$ & 22 & 18 & 26 & 13 & 0.163 \\
\hline & $\begin{array}{l}\text { Median } \\
\text { (min-max) }\end{array}$ & $\begin{array}{l}44.00 \\
(15-78)\end{array}$ & $\begin{array}{l}37.00 \\
(17-59)\end{array}$ & $\begin{array}{l}30.00 \\
(18-59)\end{array}$ & $\begin{array}{l}44.00 \\
(14-55)\end{array}$ & \\
\hline \multirow{2}{*}{$\begin{array}{l}\text { Duration of the } \\
\text { disease } \\
\text { diagnosis } \\
\text { (years) }\end{array}$} & $\mathrm{n}$ & 22 & 18 & 26 & 13 & 0.257 \\
\hline & $\begin{array}{l}\text { Median } \\
(\min -\max )\end{array}$ & $\begin{array}{l}1.00 \\
(0.5-30)\end{array}$ & $\begin{array}{l}0.50 \\
(0.75-13)\end{array}$ & $\begin{array}{l}2.00 \\
(0.75-30)\end{array}$ & $\begin{array}{l}2.50 \\
(1-16)\end{array}$ & \\
\hline \multirow[t]{2}{*}{$\begin{array}{l}\text { Morning stiffness } \\
\text { (munities) }\end{array}$} & $\mathrm{n}$ & 25 & 18 & 26 & 15 & 0.330 \\
\hline & $\begin{array}{l}\text { Median } \\
\text { (min-max) }\end{array}$ & $\begin{array}{l}30.00 \\
(0-120)\end{array}$ & $\begin{array}{l}15.00 \\
(0-120)\end{array}$ & $\begin{array}{l}22.50 \\
(0-120)\end{array}$ & $\begin{array}{l}20.00 \\
(0-60)\end{array}$ & \\
\hline \multirow[t]{2}{*}{ DAS-28 } & $\mathrm{n}$ & 25 & 18 & 26 & 15 & ${ }^{*} 0.044$ \\
\hline & $\begin{array}{l}\text { Median } \\
(\text { min-max) }\end{array}$ & $\begin{array}{l}4.86 \\
(1-6)\end{array}$ & $\begin{array}{l}3.61 \\
(2-6)\end{array}$ & $\begin{array}{l}3.93 \\
(2-7)\end{array}$ & $\begin{array}{l}3.49 \\
(2-6)\end{array}$ & \\
\hline \multirow[t]{2}{*}{ Family history } & $\begin{array}{l}\text { Yes } \\
n(\%)\end{array}$ & $4(16 \%)$ & $4(22.2 \%)$ & $11(42.3 \%)$ & $1(6.7 \%)$ & ${ }^{*} 0.041$ \\
\hline & $\begin{array}{l}\text { No } \\
n(\%)\end{array}$ & $\begin{array}{l}21 \\
(84 \%)\end{array}$ & $\begin{array}{l}14 \\
(77.8 \%)\end{array}$ & $\begin{array}{l}15 \\
(57.7 \%)\end{array}$ & $\begin{array}{l}14 \\
(93.3 \%)\end{array}$ & \\
\hline \multirow{2}{*}{$\begin{array}{l}\text { History of } \\
\text { primary and } \\
\text { secondary failure }\end{array}$} & $\begin{array}{l}\text { Yes } \\
\mathrm{n}(\%)\end{array}$ & $\begin{array}{l}0 \\
(0 \%)\end{array}$ & $\begin{array}{l}2 \\
(11.1 \%)\end{array}$ & $\begin{array}{l}1 \\
(3.8 \%)\end{array}$ & - & 0.241 \\
\hline & $\begin{array}{l}\text { No } \\
\text { n (\%) }\end{array}$ & $\begin{array}{l}25 \\
(100 \%)\end{array}$ & $\begin{array}{l}16 \\
(88.9 \%)\end{array}$ & $\begin{array}{l}25 \\
(96.2 \%)\end{array}$ & $\begin{array}{l}15 \\
(100 \%)\end{array}$ & \\
\hline
\end{tabular}


Table (3): Flowcytometry outcomes for patients and controls groups.

\begin{tabular}{|c|c|c|c|c|c|c|c|}
\hline Marker & & $\begin{array}{l}\text { MTX } \\
N(25)\end{array}$ & $\begin{array}{l}\text { Monotherapy } \\
\mathrm{N}(18)\end{array}$ & $\begin{array}{l}\text { Combined therapy } \\
N(26)\end{array}$ & $\begin{array}{l}\text { Positive control } \\
\text { N (15) }\end{array}$ & $\begin{array}{l}\text { Negative control } \\
N(13)\end{array}$ & $\begin{array}{l}\text { Sig. at } \\
\text { level of }\end{array}$ \\
\hline CD4 & $\begin{array}{l}\text { Median } \\
(\min -\max )\end{array}$ & $\begin{array}{l}32.200 \\
(15.4-66.7)\end{array}$ & $\begin{array}{l}31.500 \\
(6.3-60.7)\end{array}$ & $\begin{array}{l}32.450 \\
(7.4-62.2)\end{array}$ & $\begin{array}{l}36.300 \\
(18.0-61.8)\end{array}$ & $\begin{array}{l}29.070 \\
(22.0-41.0)\end{array}$ & 0.613 \\
\hline Th17 & $\begin{array}{l}\text { Median } \\
(\min -\max )\end{array}$ & $\begin{array}{l}19.200 \\
(4.3-32.1)\end{array}$ & $\begin{array}{l}3.100 \\
(0.7-6.7)\end{array}$ & $\begin{array}{l}4.200 \\
(1.7-14.0)\end{array}$ & $\begin{array}{l}17.300 \\
(7.1-28.6)\end{array}$ & $\begin{array}{l}0.900 \\
(0.3-4.5)\end{array}$ & ${ }^{* *} 0.01$ \\
\hline Treg & $\begin{array}{l}\text { Median } \\
(\min -\max )\end{array}$ & $\begin{array}{l}1.5000 \\
(0.54-4.20)\end{array}$ & $\begin{array}{l}3.7000 \\
(0.26-7.50)\end{array}$ & $\begin{array}{l}2.3700 \\
(0.69-3.90)\end{array}$ & $\begin{array}{l}1.8000 \\
(0.90-5.70)\end{array}$ & $\begin{array}{l}11.6500 \\
(2.10-19.23)\end{array}$ & ${ }^{* *} 0.01$ \\
\hline Foxp3 & $\begin{array}{l}\text { Median } \\
(\min -\max )\end{array}$ & $\begin{array}{l}0.7000 \\
(0.03-2.70)\end{array}$ & $\begin{array}{l}3.6000 \\
(0.20-11.00)\end{array}$ & $\begin{array}{l}1.8000 \\
(0.06-9.30)\end{array}$ & $\begin{array}{l}0.7000 \\
(0.03-2.70)\end{array}$ & $\begin{array}{l}9.2000 \\
(1.92-15.27)\end{array}$ & ${ }^{* *} 0.01$ \\
\hline $\begin{array}{l}\text { Th17/ } \\
\text { Foxp3 }\end{array}$ & $\begin{array}{l}\text { Median } \\
\text { (min-max) }\end{array}$ & $\begin{array}{l}20.4300 \\
(2.95-690.00)\end{array}$ & $\begin{array}{l}0.7050 \\
(0.18-13.50)\end{array}$ & $\begin{array}{l}2.9100 \\
(0.18-155.00)\end{array}$ & $\begin{array}{l}28.5700 \\
(7.93-830.00)\end{array}$ & $\begin{array}{l}0.1100 \\
(0.03-0.61)\end{array}$ & ${ }^{* *} 0.01$ \\
\hline
\end{tabular}

Table(4): Laboratory investigations for patients and controls groups.

\begin{tabular}{|c|c|c|c|c|c|c|c|}
\hline \multirow[t]{2}{*}{ Features } & & \multirow{2}{*}{$\begin{array}{l}\text { MTX } \\
\text { N (25) }\end{array}$} & \multirow{2}{*}{$\begin{array}{l}\text { Monotherapy } \\
\mathrm{N}(18)\end{array}$} & \multirow{2}{*}{$\begin{array}{l}\text { Combined therapy } \\
\mathrm{N}(26)\end{array}$} & \multirow{2}{*}{$\begin{array}{l}\text { Positive control } \\
\text { N (15) }\end{array}$} & \multirow{2}{*}{$\begin{array}{l}\text { Negative } \\
\text { control } \\
\mathrm{N}(13)\end{array}$} & \multirow{2}{*}{$\begin{array}{l}\text { Sig. at } \\
\text { level of }\end{array}$} \\
\hline & & & & & & & \\
\hline ESR & Median & 50.00 & 40.00 & 31.00 & 35.00 & 14.00 & 0.01 \\
\hline$(\mathrm{mm} / \mathrm{hr})$ & $(\min -\max )$ & $(5-105)$ & $(8-95)$ & $(6-110)$ & $(5-96)$ & $(7-20)$ & \\
\hline Total WBC & Median & 7.4300 & 8.1000 & 7.2500 & 7.1500 & 8.4000 & 0.767 \\
\hline$\left(10^{9} \mathrm{cell} / \mathrm{L}\right)$ & $(\min -\max )$ & $(1.00-18.00)$ & $(4.00-12.00)$ & $(4.20-15.00)$ & $(3.50-15.07)$ & $(4.80-9.90)$ & \\
\hline Total Lymphocyte & Median & 2.5900 & 2.3500 & 2.6000 & 2.0000 & 1.3000 & 0.01 \\
\hline$\left(10^{9} \mathrm{cell} / \mathrm{L}\right)$ & $(\min -\max )$ & $(1.11-7.00)$ & $(0.90-5.20)$ & $(1.52-4.70)$ & $(1.40-3.37)$ & $(0.32-1.80)$ & \\
\hline Neutrophil & Median & 4.0000 & 5.0000 & 3.9500 & 4.5300 & 3.8500 & 0.200 \\
\hline$\left(10^{9} \mathrm{cell} / \mathrm{L}\right)$ & $(\min -\max )$ & $(1.00-11.40)$ & $(3.00-8.40)$ & $(0.40-11.00)$ & $(1.20-12.20)$ & $(0.36-6.20)$ & \\
\hline Monocytes & Median & 0.3500 & 2.8000 & 1.3500 & 0.4700 & 0.1800 & 0.01 \\
\hline$\left(10^{9} \mathrm{cell} / \mathrm{L}\right)$ & $(\min -\max )$ & $(0.10-1.01)$ & $(0.47-9.90)$ & $(0.19-5.90)$ & $(0.12-0.93)$ & $(0.10-0.80)$ & \\
\hline
\end{tabular}


Table(5): Spearmann's correlations values between Th17/TregFoxp3 ratio and clinical features of patients.

\begin{tabular}{lll}
\hline Parameters & TH17/TregFoxP3 & \\
\cline { 2 - 3 } & P. value & r. value \\
\hline BMI & & \\
\hline Age of onset & 0.227 & 0.133 \\
\hline Duration of the & 0.363 & 0.104 \\
disease & & -0.085 \\
\hline Morning stiffness & 0.465 & \\
\hline
\end{tabular}

Table (6): level of Anti TNFi in patients and groups

\begin{tabular}{|c|c|c|c|c|c|}
\hline \multirow[t]{2}{*}{ Anti-TNFi } & & Monotherapy & Combined & Positive control & \\
\hline & & $N=18$ & Therapy $\mathrm{N}=26$ & $\mathrm{~N}=15$ & value \\
\hline \multirow[t]{3}{*}{ Anti-infliximab } & $+(\%)$ & $3(16)$ & $4(15)$ & $2(13)$ & 0.050 \\
\hline & Median & 7.73 & 34.35 & 10.70 & \\
\hline & (Mix-Min) & $(19.700-1.160)$ & $(42.900-17.800)$ & $(50.040-2.100)$ & \\
\hline \multirow[t]{3}{*}{ Anti-Etanercept } & $+(\%)$ & 1(5) & $2(7.2)$ & $2(13)$ & 0.134 \\
\hline & Median & 0.52 & 0.48 & 0.61 & \\
\hline & (Mix-Min) & $(0.650-0.360)$ & $(2.010-0.370)$ & $(1.050-0.390)$ & \\
\hline
\end{tabular}




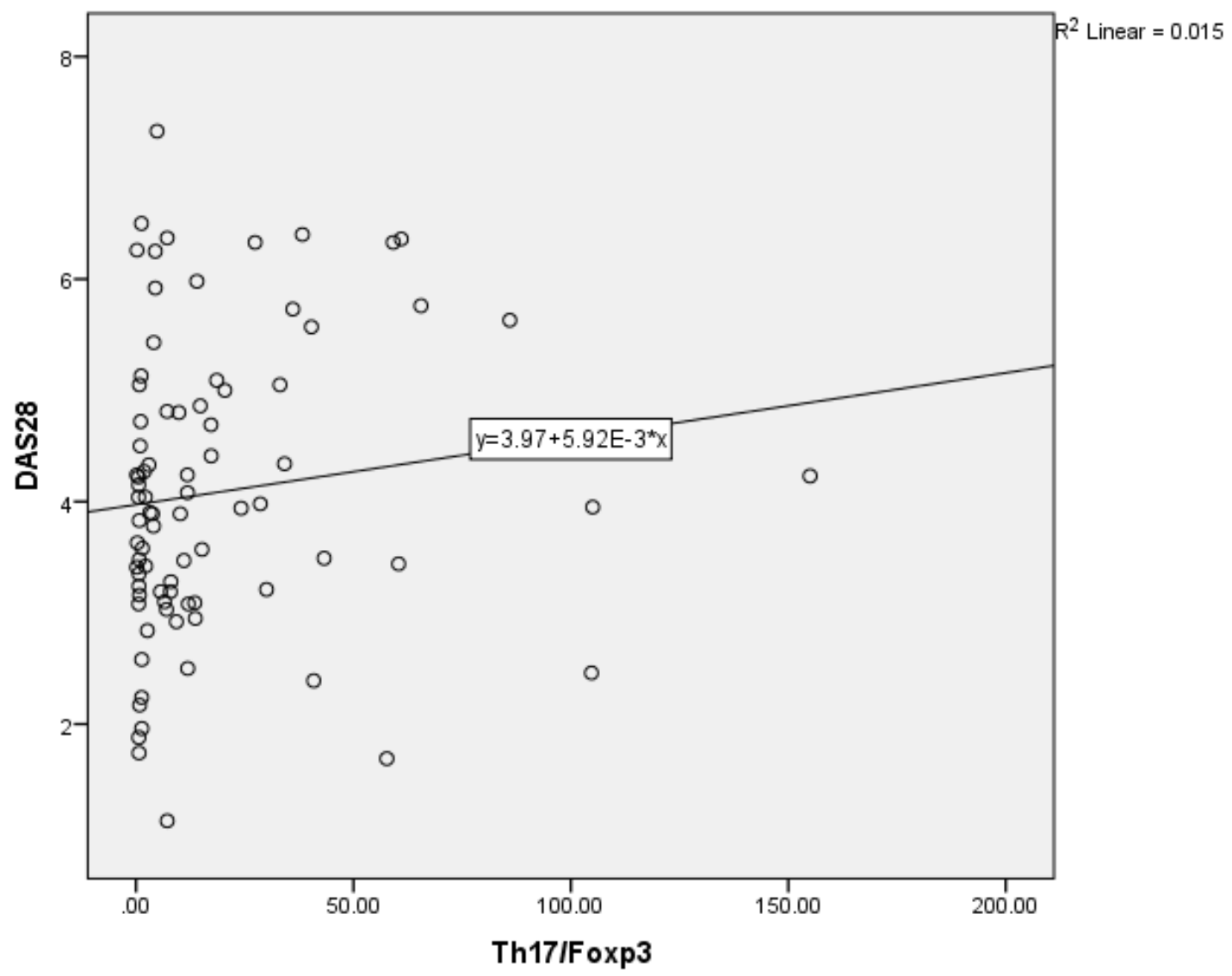

Fig. (1): Chart showing a positive significant (at the level of 0.05). Correlation betweenTh17 /Treg Foxp3+ T cells ratio and disease activity (DAS-28). score in patient's groups by Spearmann's correlation test $(r=0.231, \mathrm{P}=0.034)$ 


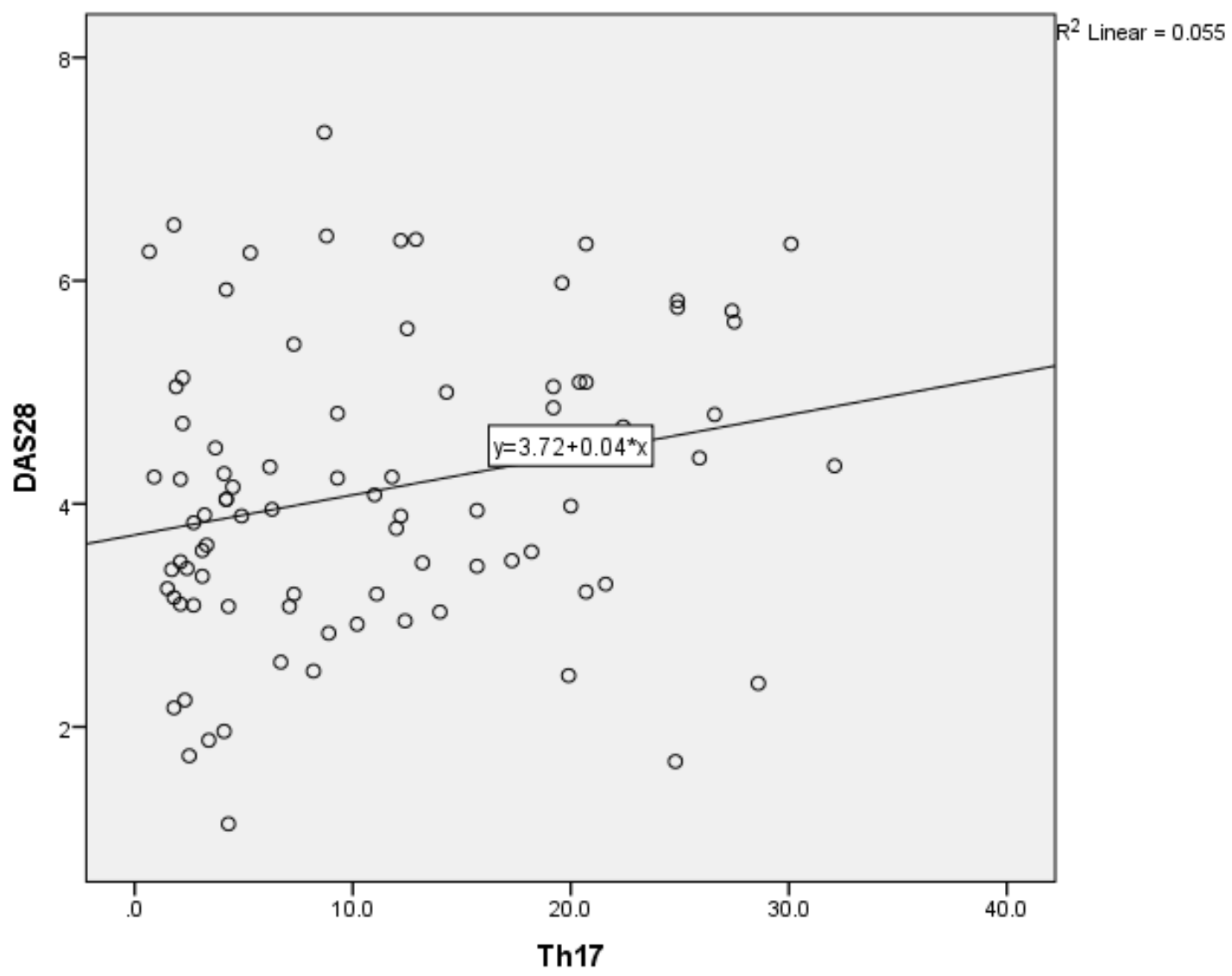

Fig. (2): Chart showing a positive significant (at the level of 0.05) correlation betweenTh17 $\mathrm{T}$ cells and disease activity score in patient's groups by Spearmann's correlation test $(\mathrm{r}=0.226, \mathrm{P}=0.039)$. 
تأثير نسبة خلايا Th17 / TregFoxp3 في مرضى التهاب المفاصل الرثوي الذين

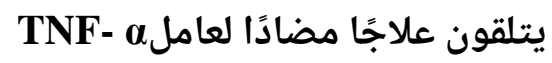

الخلاصة

من أجل تحديد العلاقة بين نشاط مرض التهاب المفاصل الروماتويدي مع نسبة خلايا / Th17

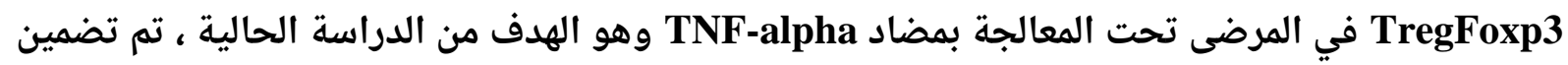
سبعة وتسعين مريضًا مصابًا بالتهاب المفاصل الروماتويدي ومجموعات تحكم صحية في هذه الحالة

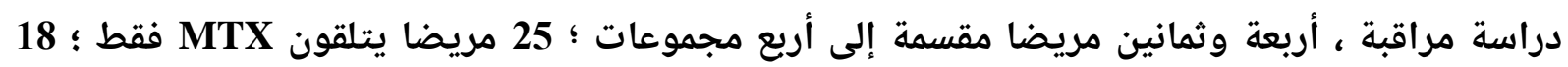

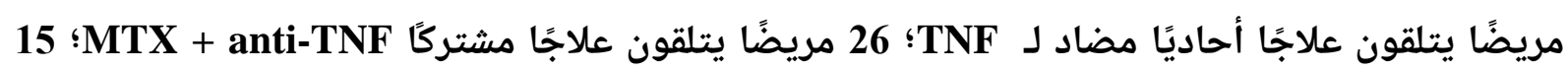
مريضًا مصابًا بالتهاب المفاصل الروماتويدي لا يتلقون أي دواء (مجموعة حاكمة ايجابية). تم تسجيل ثلاديًا ماثة

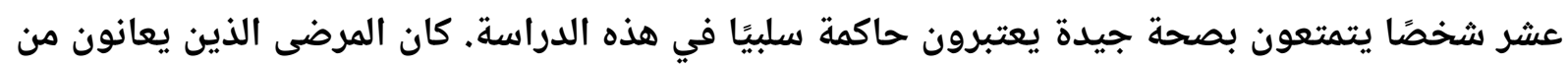

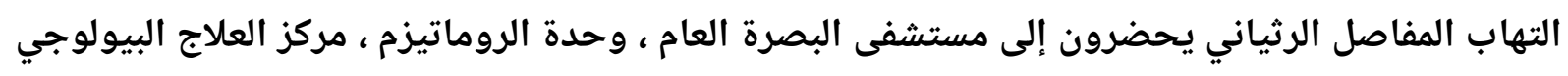

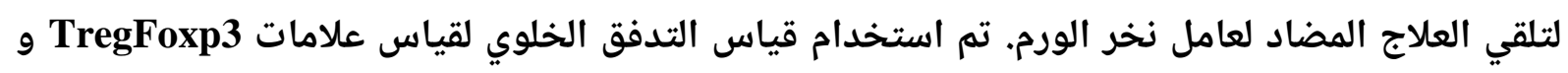
Th17 واستخدمت درجة DAS-28 لقياس نشاط مرض التهاب المفاصل الروماتويدي .تم قياس مثبطات ، ESR أيضًا. كما تم قياس المعلمات الالتهابية والدموية الأخرى إجمالي WBC ، الخلايا الليمفاوية ، وحيدات العدلات وعدد الخلايا. الناتج ، كان DAS-28 كدرجة نشاط الاط المرض مرتبطة بشكل كبير مع نسبة Th17 / TregFoxp3 ومع عدد خلايا .TH17. واحصائيا ، لم تكن نسبة ،

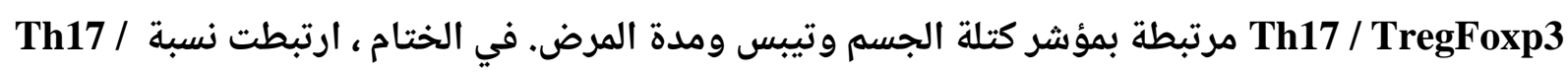

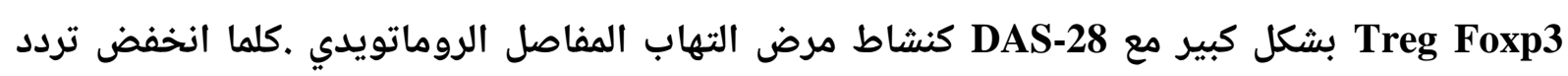

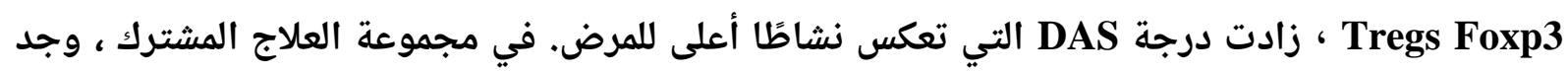

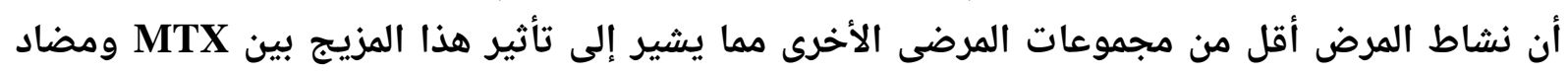

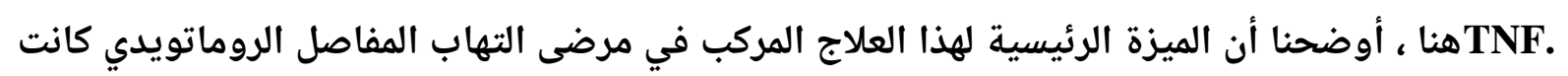

Th17. ارتداد تمدد خلايا

الكلمات المفتاحية: Anti-TNF ؛ العلاج المناعي. إنفليكسيماب. إتانرسبت. التهاب المفصل الروماتويدي؛ نسبة

Th17 / Treg Foxp 